\title{
PROMOTING STUDENTS' COLLABORATION SKILL THROUGH PROJECT BASED LEARNING OF ENGLISH WRITING
}

\author{
Farida Nova Kurniawati ${ }^{1}$, Susanto Susanto ${ }^{2}$, Ahmad Munir ${ }^{3}$ \\ ${ }^{1,2,3}$ Postgraduate Program of English Education and Literature, State University of Surabaya, Indonesia \\ farida.nova13@gmail.com ${ }^{1}$,susantoniki@gmail.com ${ }^{2}$, ahmadmunir@unesa.ac.id ${ }^{3}$
}

\begin{abstract}
This research is focused on Project Based Learning and collaboration skill of students. It is aimed to describe how Project Based Learning promotes students' collaboration skill with others as one of four Cs skills in $21^{\text {st }}$ of Century Skills. The subject of this study was five students in the ninth grade in one of state Islamic schools in Kediri. The researcher collected the data from observation and the recording video of the process of creating the project, which was wall magazine. The observation was done twice and the activities during the process of making wall magazine will be written in field note and recorded by using video recorder. This research highlights more on the process of creating the project rather than the product. Therefore, all the data will be in the form of verbal and non-verbal data. After selecting the appropriate data, the result shows that the students can reach all of indicators of collaboration skills with eleven examples as the evidences. In short, it can be concluded that Project Based Learning can promote students' collaboration.
\end{abstract}

Keywords : Project Based Learning, Collaboration Skill, Wall Magazine, Junior High School

\section{INTRODUCTION}

Nowadays, it's a challenge to be a teacher in the context of education. The teachers must be selective to choose the appropriate instructional method to teach their students. In education context, instructional method is not the only one which is crucial but also the activities. The teachers have to be creative to design the activities in teaching and learning process. The activities should be fully engaged the students' creativity also it can increase their interest and enjoyment in the process of teaching and learning. In means that the teachers should be creative on how they deliver the material. Project Based Learning $(\mathrm{PjBL})$ can be one of appropriate instructional model to be used to facilitate it.

Project Based Learning is more focused on students-centered rather than teachercentered and it can raise students' participation because most of activities are done by the students (Hadim \& Esche, 2002). The students will actively participate in the classroom and show their creativity because they have to do most of the activities by themselves. 
They can do the activities by asking their friends or teacher and they also can collaborate with other friends to solve the problems while doing the projects. The teachers will be as facilitator to give guidance and help if they have unsolved problems. Their English skill can be increased and the enjoyable classroom can be created during the practice of Poject Based Learning (Praba, Artini, \& Ramendra, 2018)

Some experts have almost similar defintion about Project Based Learning. Brown and Lee (2015) define Project Based Learning is also known as experiential learning. Experiential learning is an instructional model which emphasizes on psychomotor sides of language learning by involving the students in physical actions into which language is taught (Brown \& Lee, 2015). Experiential learning also refers to an instructional model which more emphasize on learning from life experience (Kolb, 2015). Project based learning known as project work (Harmer, 2004); (Stoller, 2002). Project work is an instructional method related to work or assignments which have given for the students in longer time period, at least 45 minutes or in one or two meetings (Harmer, 2004). Stoller (2002) is an instructional model which is finished in a final product that can be shared with others and it does not only highlight on the final product but also in the process of working the final product. In short, Project Based Learning is an instructional model which emphasizes on physical side of language learning by involving the students to do projects in the target language in one or two meeting and finished in final product that is related to their life experiences that can be shared by others.

In the practice of Project Based Learning, the students can work together in pair work or group work (Eyring, 1991). Yet, usually the teacher in junior high school will give opportunity for the students to do their project in groups. The students can work collaboratively in group through the practice of Project Based Learning. They can communicate their ideas, opinion, solve the problems, investigate what they learn with their groups and show their creativity during working together. In Project Based Learning, students are given challenging activities or projects which require collaboration and motivation (Herrington \& Herrington, 2006).

According to Praba, Artini, \& Ramendra (2018), Project Based Learning can be considered to be an approach and means to approach $21^{\text {st }}$ century skills. Those $21^{\text {st }}$ century skills are mainly consist of Four Cs, which are communication, collaboration, creativity, 
and critical thinking. However, this research is more focused on collaboration skills to make the explanation deeper. Collaboration is an activity of working together to reach similar goals (Hesse, Care, Buder, Sassenberg, \& Griffin, 2015). Bell (2010) states that students can work or collaborate together as well as they are involving in developing the project. By doing the project, the students can work and collaborate together also share their ideas and knowledge with others (Sholihah, 2017). It means that their collaboration skill is required in the implementation of Project Based Learning.

From the explanation above, it implicitly shows that Project Based Learning might promote students' collaboration skills because it allows learners to work collaboratively in pair or in group as well. Solomon (2003) argues that Project Based Learning involves students' collaboration skills. The students' collaboration skills also can be improved through the implementation of Project Based Learning (Dewi, 2016). While Sawamura (2010) argues that Project Based Learning can motivate and improve collaboration and communication skills of the students. However, all of those studies did not give deep explanation and clear evidences that Project Based Learning might promote students' collaboration skill. Therefore, to fill this gap, the researcher conducts a research to investigate how Project Based Learning might promote collaboration skill of the students. This research is aimed to describe how Project Based Learning (PjBL) promotes students' skill to collaborate with others in the process of learning writing. The researcher formulate a research question to investigate it, as follow: "How does Project Based Learning promote students' collaboration skill in the process of learning writing?"

\section{METHOD}

The researcher will use case study as research design to investigate how Project Based Learning promotes students' collaboration skill in the process of learning writing. Case study is a complete and depth observation of a social unit, it can be one person, one family, one institution, one cultural group, or it also can be the entire community (Kothari, 2004). The researcher will select randomly a group in a class to be investigated and observed. Therefore, case study is chosen to be used as research design for this research.

The subjects of this study are the ninth grade students in one class in one of state Islamic junior high school in Kediri, East Java. One class in this school will be used as the setting of this research. The class is in good condition and quite spacious. In this class, 
here are thirty eight students consist of twenty three girls and fifteen boys. To make the observation more focus and more detail, the researcher will randomly choose a group to be observed. This group will be the main subject of the research. The researcher will observe fully to this group to investigate on how project based learning promote students' collaboration skill.

The data in this research will be in the form of utterances or conversations said by the teacher and the students. Another data is from teacher and students' gestures also body movement. The result or product of students' project also will be the data of the research as well. Meanwhile, the sources of the data are from verbal and non-verbal behavior from teacher and the students.

The researcher collects the data from observation. The researcher will do observation twice. In the observation, the researcher makes no special effort to have a particular role in the setting; to be tolerated as an unobtrusive observer is enough (Marshall \& Rossman, 2006). It means that the researcher will not participate in the classroom or will be non-participant observation to avoid students from behaving unnaturally. All the activities in the classroom will be recorded in the video recorder. For a group which has randomly chosen by the researcher, their verbal and non-verbal behavior in the classroom will be recorded. The chosen group consists of five girl students. All their verbal and nonverbal behavior will be recorded as the data for this research. The data from recording and students' final product will be used by the researcher as additional information to complete the data from observation.

After collecting the data, the researcher uses three steps of analyzing the data from Miles, Huberman, \& Saldana (2014) to analyze all the data. Those three steps are data condensation, data display, and drawing conclusion. The indicators of collaboration skill from Ahmad (2018) are used to investigate how Project Based Learning promotes students' collaboration skill in the process of learning writing. Here are the indicators:

Table 1. Indicators of Collaboration Skill

\begin{tabular}{|c|l|rl|}
\hline No & \multicolumn{1}{|c|}{ Collaboration Skills } & \multicolumn{1}{c|}{ Indicators } \\
\hline 1. & $\begin{array}{l}\text { Students have empathy } \\
\text { and always appreciate } \\
\text { different perception or } \\
\text { opinion from others }\end{array}$ & a. $\begin{array}{l}\text { Students can give opportunity and motivation to others } \\
\text { to express their opinion or idea. }\end{array}$ \\
b. $\begin{array}{l}\text { Students can consistently support and respect the effort } \\
\text { of others by praising their opinion/idea and their work }\end{array}$ \\
\hline
\end{tabular}




\begin{tabular}{|c|c|c|}
\hline & $\begin{array}{l}\text { through spoken, written, } \\
\text { or even body language. }\end{array}$ & $\begin{array}{l}\text { as well. } \\
\text { c. Students can give suggestion or comment politely if } \\
\text { others' opinion or idea does not appropriate to the } \\
\text { project. }\end{array}$ \\
\hline 2. & $\begin{array}{l}\text { Students discuss and } \\
\text { decide the final decision } \\
\text { of the project. }\end{array}$ & $\begin{array}{l}\text { a. Students can give opinion or idea during the } \\
\text { discussion. } \\
\text { b. Students can decide their shared responsibility to finish } \\
\text { the project. } \\
\text { c. Students can do the project cohesively by doing it } \\
\text { together even they have different task in group but } \\
\text { they can do it well and they have willingness to } \\
\text { consistently help the other member if he / she has } \\
\text { difficulties while doing their task. }\end{array}$ \\
\hline
\end{tabular}

\section{RESULT}

There are many examples of project based activities, as follow hands-on project, field trips and other on-visits (going to a factory or museum), research projects (value of wind power), extra-class dinner groups (learning about Korean cuisine), and creating a video to promote a product (Brown \& Lee, 2015). In this research, the project is about the hands-on project. It is wall magazine. The teacher asked the students to make wall magazine. The students had to make wall magazine which was related to descriptive text. The teacher gave freedom to them to decide what theme that they wanted to be described. The students were given for about a week to finish their project.

To investigate students' collaboration skill during the practice of Project Based Learning, the researcher was done observation twice. The observations were done when they were working on the project, the researcher observed their verbal and non-verbal behavior. Through students' verbal and non-verbal behavior, they indicated whether Project Based Learning could or could not promote their collaboration skill. The verbal data were from students' utterances or conversations which are uttered the students in the classroom when they were working on the project. While the non-verbal data were students' gestures, facial contact also body movement. These data would be used as the clear evidences whether the students' collaboration skill could be promoted through the practice of Project Based Learning. Those data would be filtered by using six indicators above to select appropriate data that would be used as the finding of this research.

From all the observations, the result showed that Project Based Learning could promote students' collaboration skill. The evidences can be seen in the Table 2. As it was 
explained before, there were five girls students. In the Table 2, S1 is stands for student 1 , S2 is stands for student 2, S3 is stands for student 3, S4 is stands for student 4, and S5 is stands for student 5 . Here is the result:

Table 2. Result

\begin{tabular}{|c|c|c|}
\hline No & Indicators & Evidences \\
\hline 1. & $\begin{array}{l}\text { Students can give } \\
\text { opportunity and motivation } \\
\text { to others to express their } \\
\text { opinion or idea. }\end{array}$ & $\begin{array}{l}\text { a. S3: Aku mau ngasih ide ya ke kalian (I want to share my idea to you } \\
\text { guys) } \\
\text { S1 : Oke, silahkan dong (Ok, please) } \\
\text { S2: Okee (Ok) } \\
\text { S4 \& S5 : Yes, sure } \\
\text { b. S3 : Gini gini, aku punya ide. Tapi nggak tau ini bermanfaat apa } \\
\text { nggak (Like this, I've an idea. But I don't know it'll be useful or not) } \\
\text { S4: Nggak papa kok, coba aja. Tetep kita hargai. Gimana idemu? } \\
\text { (It's okay, just try it. We still appreciate it. How is your idea?) } \\
\text { S3: Gimana kalo Pake gelas minuman aja buat bentuk bulat? (How if } \\
\text { we use a glassto make round shape) } \\
\text { S4: Oh iyaya, bener juga. Good idea! (Oh yeah, that's right. Good } \\
\text { idea!) }\end{array}$ \\
\hline 2. & $\begin{array}{l}\text { Students can consistently } \\
\text { support and respect the } \\
\text { effort of others by praising } \\
\text { their opinion/idea and their } \\
\text { work as well. }\end{array}$ & $\begin{array}{l}\text { a. S3 : Gimana kalo kita nunggu deskripsinya selesai? Aku takut kalo } \\
\text { nanti kita salah tempat buat nempelin gambarnya, jadi kita harus } \\
\text { nunggu mereka nyelesein deskripsinya. (How if we wait until the } \\
\text { description is done? I'm afraid if later we stick it in the wrong } \\
\text { position, so we have to wait until they finish the description) } \\
\text { S1 : Oke, brilliant! (Ok, brilliant!) } \\
\text { S2 \& S4 : Setuju (Agree) } \\
\text { S5 : Ide bagus (Good idea) } \\
\text { b. S3: (Menunjuk kertas origami) Maka dari itu aku ambil ini. } \\
\text { (Pointing at origami paper) (That's why I take this). } \\
\text { S2: (Memberi pujian dengan mengajungkan tangan ke S3). (Giving } \\
\text { compliment by giving thumbs up to S3) } \\
\text { S1 : Very good }\end{array}$ \\
\hline 3. & $\begin{array}{l}\text { Students can give } \\
\text { suggestion or comment if } \\
\text { others' opinion or idea } \\
\text { politely if it does not } \\
\text { appropriate to the project. }\end{array}$ & $\begin{array}{l}\text { a. S3: Eh, kalo kita gambar pohon- pohon disini gimana? (Ehm, how } \\
\text { about if we draw some trees here?) } \\
\text { S2 : Oke, great idea! Jadi kan nanti kayak ada suasana hutan gitu. } \\
\text { Tapi pohon e nggak usah dibuat 3D, jadi biar semua nggak 3D. Biar } \\
\text { nggak monoton (Ok, great idea! So, it feels like there is an ambiance } \\
\text { of forest. But, no need to make 3D for trees, so not all the things are } \\
\text { 3D.To make it not too monotonous) } \\
\text { S3 : Nggak kok, kan pohonnya cuma buat tambahan dekorasi aja. } \\
\text { (No, the trees only for additional decoration ) } \\
\text { S2: Ya bener, kita punya pemahaman yang sama (Yap, we have } \\
\text { same understanding) } \\
\text { b. S3: Apa itu? Ini ide dari saya. Kertasnya dibuka kan terus } \\
\text { dibentangkan. Itu nanti lebih gampang. (What is that? This idea id } \\
\text { from me. The paper will be open then spread out. It will be easier) } \\
\text { S1 : Kita enaknya pake kertas warna merah atau pake warna yang } \\
\text { lebih tidak mencolok? We're better to use red paper or use less } \\
\text { flashy color? } \\
\text { S2 : Kalau menurutku jangan merah (I think don't use red) } \\
\text { S3 : Merah, kalo menurutku (Red, I think) } \\
\text { S4 : Ini? (Ungu) (This? (purple)) } \\
\text { S1 : Ini lo (Ungu) (This is (purple)) } \\
\text { S4 : Apa ini ? (Kuning) (How about this? (Yellow)) }\end{array}$ \\
\hline
\end{tabular}




\begin{tabular}{|c|c|c|}
\hline & & $\begin{array}{l}\text { S2: Tapi menurutku kalua ungu warnanya terlalu pudar (But for me } \\
\text { purple is too faded) } \\
\text { S1: Apa kuning? (What about yellow?) } \\
\text { S2: Yaudah wes merah aja nggak papa (Red is okay) } \\
\text { S3 : Soalnya kan merahnya sama ini nggak sama (Because this red } \\
\text { and that red is different) }\end{array}$ \\
\hline 4. & $\begin{array}{l}\text { Students can give opinion } \\
\text { or idea during the } \\
\text { discussion. }\end{array}$ & $\begin{array}{l}\text { a. S3: Gimana kalo aku gambar batangnya kayak gini ? Oke nggak ? } \\
\text { (How if I draw the trunk like this? Is it okay? ) } \\
\text { S2: Bagus kok (It's good) } \\
\text { b. S2: Ini mau ditempel dimana? (Where will this be sticked?) } \\
\text { S1: Kayaknya sini aja sih atau disitu? (here or there?) } \\
\text { S2: Mending disini aja lebih bagus. Gimana yang lain? (It's better } \\
\text { here. How about you guys?) } \\
\text { S3: Kalo aku mending disini aja (I think it's better here) } \\
\text { S4 : Iya disini aja bagus, lebih pas (Yeah, here is better, more } \\
\text { suitable) } \\
\text { S5: Yap bener sini aja (Yap, here ) } \\
\text { c. S2: La terus nanti kita hias gambar animals nya gitu biar nggak } \\
\text { monoton dan nggak kotak-kotak gitu lo (And then we decorate the } \\
\text { pictures of animals in order to make it not too monotonous and the } \\
\text { shape is not just square) } \\
\text { S1: Oke nggak papa, oke lanjut (No problem, let's continue) }\end{array}$ \\
\hline 5. & $\begin{array}{l}\text { Students can decide their } \\
\text { shared responsibility to } \\
\text { finish the project. }\end{array}$ & $\begin{array}{l}\mathrm{S} 1 \text { : Oke. Oke ayo kita ngehias ini. S5 kamu yang bagian deskripsi ya } \\
\text { (Ok. Let's start to decorate it. S5, you can take part in description). } \\
\mathrm{S} 5 \text { : Oke, aku buat deskripsi sama S4 ya? (Ok, I'll make the description } \\
\text { with S4 huh?) } \\
\mathrm{S} 4 \text { : Iya aku sama S5 buat deskripsi (Yes, I'll make the description with } \\
\text { S5) } \\
\mathrm{S} 3 \text { : Kalo gitu aku, S1, S2 ngehias wall magazine nya ya (If it's so, S1, } \\
\text { S2, and I will decorate the wall magazine, huh?) } \\
\mathrm{S} 2 \text { : Iya setuju, biar cepet selesai ya . (Ok, agree, in order we can finish it } \\
\text { faster) }\end{array}$ \\
\hline 6. & $\begin{array}{l}\text { Students can do the project } \\
\text { cohesively by doing it } \\
\text { together even they have } \\
\text { different task in group but } \\
\text { they can do it well and they } \\
\text { have willingness to } \\
\text { consistently help the other } \\
\text { member if he / she has } \\
\text { difficulties while doing } \\
\text { their task. }\end{array}$ & $\begin{array}{l}\text { S3 : Nanti kalau belum selesai dibantuin. Ayo ! Aku mau buat judulnya } \\
\text { dulu ya. (If you don't finish it yet, we'll help you. Let's start! I'll } \\
\text { make the title first). } \\
\text { S2 : Iya kalo ada kesulitan juga pasti kita bantu (Yeah, if there's any } \\
\text { difficulties we'll help you) } \\
\text { S5 : Yauda kalo gitu, tak coba semaksimal mungkin (If it's so, I'll do my } \\
\text { best) }\end{array}$ \\
\hline
\end{tabular}

\section{DISCUSSION}

Project Based Learning can be practiced in many ways. Wall magazine is one of kinds of Project Based Learning. Project Based Learning also known as experiential learning (Brown \& Lee, 2015); (Kolb, 2015) and project work (Harmer, 2004); (Stoller, 2002). This is related to the practice of wall magazine as well because it emphasizes on 
physical side of language learning by involving the students to do projects in their target language which is English then they can create finished final product (wall magazine) that is related to their life experiences and it can be shared by others.

They were doing their wall magazine in two meetings. It means that the researcher was done the observation two times which are in first and second meeting. In the first observation, the teacher explained about descriptive text first. After the students had understood about it, the teacher divided the students became some groups. Then, he gave the example of wall magazine to the students. Every group was given a picture of the example of wall magazine. Next, the teacher asked them to make wall magazine as their project.

The researcher chose a group randomly as the subject of this research. It is aimed to make the observation can be more focused and detail. The students discussed their concept for their wall magazine in the first observation. The teacher gave freedom for the students to choose the theme. They chose social media and Youtubers as their first theme. However, they thought this theme was difficult. Then, they decided to change their theme became animals of Indonesia. Through this discussion, the researcher would know their collaboration skill can be seen or not. They shared their opinion, giving comment and advice to others also appreciate every ideas which had shared. They could solve their problem by discussing it together. The researcher could see their plan as well for their wall magazine. They decided what animals that they would describe, what paper or what color of markers that they used, and who should make the description and make decoration.

In the second observation, the researcher observed all the process when they worked on their project. Started from when they decided the task for every member of the group. Three members did the decoration of the wall magazine and the two members made the descriptive text of animals in Indonesia. Three members started to prepare all the material for wall magazine. There were styrofoam, manila papers, origami papers, and markers. The two members started to find some example of descriptive text in some sources. Then, they make the descriptive text by their own. The sources are used as their references to describe the animals of Indonesia.

From the selected data from observation, it can be seen that Project Based Learning can promote students' collaboration skill. There are six indicators used to investigate it and 
the students can reach all of those indicators. All of those indicators were adapted from Ahmad (2018) used to filter all the data from the observation and the recording video. During the observation, the researcher reported the activities and the situation in the practice of Project Based Learning. For the recording video, it is transcribed first then the researcher selected the appropriate data by using the indicators.

Students' collaboration skill can be promoted through the practice of Project Based Learning. It can be seen from every indicator that they had reached. First indicator is students can give opportunity and motivation to others to express their opinion or idea. There are two examples of students' utterances which reflect that indicators. First example is:

\section{Example 1}

S3: Aku mau ngasih ide ya ke kalian (I want to share my idea to you guys)

S1 : Oke, silahkan dong (Ok, please)

$\mathrm{S} 2$ : Okee $(O k)$

S4 \& S5 : Yes, sure

Example 2

S3 : Gini gini, aku punya ide. Tapi nggak tau ini bermanfaat apa nggak (Like this, I've an idea. But I don't know it'll be useful or not)

S4 : Nggak papa kok, coba aja. Tetep kita hargai. Gimana idemu? (It's okay, just try it. We still appreciate it. How is your idea?)

S3: Gimana kalo Pake gelas minuman aja buat bentuk bulat? (How if we use a glassto make round shape)

S4: Oh iyaya, bener juga. Good idea! (Oh yeah, that's right. Good idea!)

From the example 1, S3 told the other members of the group that they wanted to share her idea. Then the other members gave her opportunity to share her idea by let her to tell it. S1, S2, and S4 gave support to S2 by giving response such as "Ok please" or "Yes sure" to make S2 braver to share her ideas. In the example 2, S4 gave motivation to S3 to try to be braver to express her idea by commenting "It's okay, just try it. We still appreciate it. How is your idea?" By giving this response, S3 was more confident to express her idea and in the end S4 gave her compliment by saying "Good idea". These two examples showed that the students can reach the first indicator of collaboration skill.

Example 3

S3 : Gimana kalo kita nunggu deskripsinya selesai? Aku takut kalo nanti kita salah tempat buat nempelin gambarnya, jadi kita harus nunggu mereka nyelesein deskripsinya. (How if we wait until the description is done? I'm afraid if later we stick it in the wrong position, so we have to wait until they finish the description) $\mathrm{S} 1$ : Oke, brilliant! (Ok, brilliant!)

S2 \& S4 : Setuju (Agree)

S5 : Ide bagus (Good idea)

Example 4 
S3 : (Menunjuk kertas origami) Maka dari itu aku ambil ini. (Pointing at origami paper) (That's why I take this).

S2 : (Memberi pujian dengan mengajungkan tangan ke S3). (Giving compliment by giving thumbs up to S3)

The second indicator of collaboration skill from Ahmad (2018) is students can consistently support and respect the effort of others by praising their opinion/idea and their work as well. The students also can reach this indicator. Yet, the evidences were a bit different. In the example 3, S1, S2, S3, S4 giving compliment to S3's opinion spoken. After S3 share her idea, they gave various compliment such as: "Brilliant!; Agree; and Good idea". While in the example 4, S2 praised S3's opinion by showing her gestures which is giving thumbs up to S3. Although the evidences are bit different, they still can reach the second indicator well.

\section{Example 5}

$\mathrm{S} 3$ : Eh, kalo kita gambar pohon- pohon disini gimana? (Ehm, how about if we draw some trees here?)

S2 : Oke, great idea! Jadi kan nanti kayak ada suasana hutan gitu. Tapi pohon e nggak usah dibuat 3D, jadi biar semua nggak 3D. Biar nggak monoton (Ok, great idea! So, it feels like there is an ambiance of forest. But, no need to make $3 D$ for trees, so not all the things are 3D.To make it not too monotonous)

S3 : Nggak kok, kan pohonnya cuma buat tambahan dekorasi aja. (No, the trees only for additional decoration )

S2 : Ya bener, kita punya pemahaman yang sama (Yap, we have same understanding)

\section{Example 6}

S3 : Apa itu? Ini ide dari saya. Kertasnya dibuka kan terus dibentangkan. Itu nanti lebih gampang. (What is that? This idea id from me. The paper will be open then spread out. It will be easier)

$\mathrm{S} 1$ : Kita enaknya pake kertas warna merah atau pake warna yang lebih tidak mencolok? (We're better to use red paper or use less flashy color?)

$\mathrm{S} 2$ : Kalau menurutku jangan merah (I think don't use red)

S3 : Merah, kalo menurutku (Red, I think)

S4 : Ini ? (Ungu) (This? (purple))

$\mathrm{S} 1$ : Ini lo (Ungu) (This is (purple))

S4 : Apa ini ? (Kuning) (How about this? (Yellow))

S2 : Tapi menurutku kalau ungu warnanya terlalu pudar (But for me purple is too faded)

$\mathrm{S} 1$ : Apa kuning? (What about yellow?)

S2 : Yaudah wes merah aja nggak papa (Red is okay)

S1 : Oke deh $(O k)$

$\mathrm{S} 3$ : Oke, ayaknya emang yang paling bagus merah $\operatorname{sih}(\mathrm{Ok}$, it seems like red is the best)

From example 5 and example 6, it can be seen that the students can achieve the third indicator which is they can give suggestion or comment if others' opinion or idea politely if it does not appropriate to the project. S2 showed her suggestion to S3 when she expressed her idea in the example 5. S2 praised S3's idea but she added a suggestion to make the project better by saying "Ok, great idea! So, it feels like there is an ambiance of forest. But, no need to make 3D for trees, so not all the things are 3D.To make it not too monotonous". In the example 6, S1 asked others whether used red or flashy color. Most of 
them did not agree to use red or flashy color in the beginning. S2 commented that do not use red, while S4 and S1 commented purple. Yet, S2 said that purple is too faded. They still speak politely to others even there is opinion from one of them which is not appropriate to the project.

\section{Example 7}

S3: Gimana kalo aku gambar batangnya kayak gini ? Oke nggak ? (How if I draw the trunk like this? Is it okay? )

S2 : Bagus kok (It's good)

Example 8

$\mathrm{S} 2$ : Ini mau ditempel dimana? (Where will this be sticked?)

$\mathrm{S} 1$ : Kayaknya sini aja sih atau disitu? (here or there?)

S2 : Mending disini aja lebih bagus. Gimana yang lain? (It's better here. How about you guys?)

S3 : Kalo aku mending disini aja (I think it's better here)

S4 : Iya disini aja bagus, lebih pas (Yeah, here is better, more suitable)

S5 : Yap bener sini aja (Yap,here)

Example 9

S2 : La terus nanti kita hias gambar animals nya gitu biar nggak monoton dan nggak kotak-kotak gitu lo (And then we decorate the pictures of animals in order to make it not too monotonous and the shape is not just square)

S1 : Oke nggak papa, oke lanjut (No problem, let's continue)

Indicator number four is students can give opinion or idea during the discussion. Example 7 shows the evidence that S3 feel free give opinion when she was drawing the trunk of the tree as the decoration of wall magazine. S2 also gave good comment toward it. In the example $8, \mathrm{~S} 1, \mathrm{~S} 2, \mathrm{~S} 3, \mathrm{~S} 4, \mathrm{~S} 5$ give their own opinion about the best place to stick the decoration for wall magazine. Every student expresses their opinion about it. It is same as example 9, S2 told her opinion to decorate the pictures of animals in order to make it not too monotonous while S1 agree with her idea. In short, they can achieve the fourth indicator of collaboration skill.

\section{Example 10}

S1 : Oke. Ayo kita ngehias ini. S5 kamu yang bagian deskripsi ya (Ok. Let's start to decorate it. S5, you can take part in description).

S5 : Oke, aku buat deskripsi sama S4 ya? (Ok, I'll make the description with S4 huh?)

S4 : Iya aku sama S5 buat deskripsi (Yes, I'll make the description with S5)

$\mathrm{S} 3$ : Kalo gitu aku, S1, S2 ngehias wall magazine nya ya (If it's so,S1, S2, and I will decorate the wall magazine, huh?)

$\mathrm{S} 2$ : Iya setuju, biar cepet selesai ya . (Ok, agree, in order we can finish it faster)

Students can decide their shared responsibility to finish the project is the fifth indicator of collaboration skill. This indicator relate to their decision to divide the task or to share responsibility when they were working on their project. This can be seen as well from their utterances whether they can divide the task or not. Based on the example 10, it 
can be proven that they can reach the fifth indicator. S1, S2, and S3 were decorating wall magazine while S4 and S5 were making descriptive text of animals in Indonesia. It reflects that they can share the responsibility to work on the project by themselves.

Example 11

S2 : Ayo kita kerjakan bersama dengan pembagian tugas yang kayak tadi ya. Kalo ada kesulitan ngomong. (Let's do it together with our own tasks which have decided before. Tell us if there issome difficulties)

S3 : Nanti kalau belum selesai dibantuin. Ayo ! Aku mau buat judulnya dulu ya. (If anyone of you don't finish it yet, we'll help you. Let's start! I'll make the title first).

S2 : Iya kalo ada kesulitan juga pasti dibantu (Yeah, if there's any difficulties we'll help you)

S5 : Yauda kalo gitu, tak coba semaksimal mungkin (If it's so, I'll do my best)

Last but not least is the sixth indicator. The students can reach this indicator if they can do the project cohesively by doing it together even they have different task in group but they can do it well and they have willingness to consistently help the other member if he / she has difficulties while doing their task. They still work on their project together and cohesively but they have their own tasks which have decided before. Even they have different task, they still give chance for others to ask some questions or to tell the difficulties to other members of the group. The other members will absolutely help the member which faces some difficulties. In short, the students can reach the last indicator of collaboration as well and the evidence can be seen from the example 11.

\section{CONCLUSION}

This study was aimed to describe how Project Based Learning promotes students' collaboration skill especially for the ninth grade of junior high school. In this study, the researcher formulated one research question, as follow: How does Project Based Learning promote students' collaboration skill? In order to answer it, the researcher was done observation twice. Field note was used in the observation to report the activities and situation during the practice of Project Based Learning. In the first observation, the researcher observed their discussion activity when they discussed the concept of their project, which was wall magazine. The researcher observed all of their verbal and nonbehavior when they were developing their wall magazine in the second observation. The verbal and non-verbal behaviors were used as the data for this research.

After all the data have been collected, the researcher analyzed it by using Miles, Huberman, \& Saldana (2014). The researcher selected the appropriate data by using indicators of collaboration skill from Ahmad (2018). From the data which have been 
analyzed, it can be concluded that Project Based Learning can promote students' collaboration skill. As the evidences of this statement, the students have reached all of the indicators of collaboration skill and there are eleven examples as proof that they can reach it. To follow the conclusion, Project Based Learning is highly applicable because it can promote students' collaboration skill. For the future researchers in this topic, they can use the result of this research as a reference to conduct a research about project based learning and students' Four Cs of skills especially collaboration skill or it can be other four Cs skills such as communication skill, creativity, and critical thinking skill in the different area of teaching.

\section{REFERENCES}

Ahmad, S. (2018). Meningkatkan kemampuan kolaborasi siswa kelas XI SMA Islam AlWodir mengggunakan model TPS pada materi sistem reproduksi. Kediri: Universitas Nusantara PGRI.

Ahmad, S. (2018). Meningkatkan kemampuan kolaborasi siswa kelas XI SMA Islam AlWodir menggunakan model TPS pada materi sistem reproduksi. Kediri: Universitas Nusantara PGRI.

Bell, S. (2010). Project based learning for the 21st century: Skills for the future. The Clearing House: A Journal of Strategies, 83(2), 39-43.

Brown, H., \& Lee, H. (2015). Teaching by principlr: An interactive approach to language pedagogy (4th ed.). New York: Pearson Education, Inc.

Dewi, H. (2016). Project based learning techniques to improve speaking skills. English Education Journal, 7(3), 341-359.

Eyring, J. (1991). Experiential language learning. In M. Celce-Muria, Teaching English as a second or foreign language (2nd ed., pp. 346-357). Boston: Henle \& Henle.

Hadim, H. A., \& Esche, S. (2002). Enhancing the engineering curriculum through project based learning. Frontiers in Education.

Harmer, J. (2004). The practice of English language teaching (3rd ed.). Essex: Pearson Education Limited.

Herrington, A., \& Herrington, J. (2006). What is an authentic learning environment? . In A. Herrington, \& J. \& Herrington, Authentic environments in higher education (pp. 1-14). Hershley PA: Idea Group. 
Hesse, F., Care, E., Buder, J., Sassenberg, K., \& Griffin, P. (2015). A framework of teachable collaborative problem solving skills. In P. Griffin, \& E. Care, Assessment and teaching of 21st century skills: Methods and approach (pp. 37-56). Dordrecht, NL: Springer.

Kolb, D. A. (2015). Experiential Learning (2nd ed.). New Jersey: Pearson Education.

Kothari, C. (2004). Research methodology: Methods and techniques (2nd ed.). New Delhi: New Age International Publishers.

Marshall, C., \& Rossman, G. (2006). Designing qualitative research (4th ed.). Thousand Oaks: Sage Publication.

Miles, M., Huberman, A., \& Saldana, J. (2014). Qualitative data analysis: A methods sourcebook (3rd ed.). Thousand Oaks: Sage Publication, Inc.

Praba, L., Artini, L., \& Ramendra, D. (2018). Project based learning and writing skill in EFL: Are they related? SHS Web Conferences. 42. EDP Sciences. doi:https://doi.org/10/1051/shsconf/20184200059

Sawamura, S. (2010). Assessment in project based language learning. Hawaii Pacific University TESOL, 8(1,2), 44-49.

Sholihah, U. (2017). Project based learning to improve students' writing capability. Science, Engineering, Education, and Development Studies (SEEDs) Conference Series, 1(1), 57-72.

Solomon, G. (2003). Project-based learning: A primer. Technology and learning, 23(6), 20-26.

Stoller, F. (2002). Project-work: A means to promote language and content. In J. Richards, $\&$ W. Renandya, Methodology in language teaching: AN anthology of current practice (pp. 107-120). Cambridge: Cambridge University Press. 